Aneta BĄK-SZOŁUCHA ${ }^{1}$

DOI: https://doi.org/10.53052/9788366249875.06

\title{
STRATEGIE KOMUNIKACYJNE PAŃSTWOWYCH UCZELNI TECHNICZNYCH PODCZAS PIERWSZEJ FALI PANDEMII
}

\begin{abstract}
Streszczenie: W artykule przedstawiono wyniki badań nad aktywnością publicznych uczelni wyższych w mediach społecznościowych. Analizie poddano proces komunikacji za pomocą Facebooka uczelni wyższych w Polsce w okresie od 4 marca do 30 czerwca 2020 roku podczas pierwszej fali pandemii koronowirusa. Badania wykazały, że uczelnie techniczne najczęściej wykorzystywały tego rodzaju narzędzia do komunikacji ze społecznością akademicką, aczkolwiek najczęściej publikując posty niedotyczące sytuacji pandemicznej.
\end{abstract}

Słowa kluczowe: komunikacja, social media, nowe technologie, Facebook, uczelnie wyższe

\section{COMMUNICATION STRATEGIES OF PUBLIC TECHNICAL UNIVERSITIES DURING THE FIRST WAVE OF THE PANDEMIC}

\begin{abstract}
Summary: The article presents the results of research on the activity of public universities in social media. Facebook communication of universities in the period from March 4 to June 30, 2020 during the coronovirus pandemic was analyzed. As the results show, technical universities most often used Facebook to communicate with the academic community, although they published posts not related to the pandemic situation.
\end{abstract}

Keywords: communications, social media, new technology, Facebook, universities

\section{Wprowadzenie}

Sprawna komunikacja zarówno z otoczeniem zewnętrznym jak i zewnętrznym to zdecydowanie jeden z czynników świadczących o sukcesie danego podmiotu. Posiadanie i dostęp do informacji we współczesnym świecie, to istotny element globalnej rzeczywistości, w której sprawne komunikowanie w dużej mierze decyduje o pozycji i znaczeniu danego podmiotu, bowiem to właśnie informacja lub jej brak decyduje o przewadze konkurencyjnej. Skuteczne zarządzanie informacją w otoczeniu o silnej konkurencji rynkowej zmusza przedsiębiorstwa do zmiany

1 dr, Akademia Techniczno-Humanistyczna w Bielsku-Białej, Wydział Zarządzania i Transportu, Katedra Nauk Ekonomicznych i Społecznych, abak@ath.bielsko.pl 
sposobu komunikowania się $\mathrm{z}$ otoczeniem oferując swoje produkty lub usługi. Najważniejsze staje się szukanie nowych rozwiązań zwiększających efektywność dotarcia $\mathrm{z}$ przekazem do odbiorców. Istotą dobrze zaprojektowanej strategii komunikacyjnej jest budowania relacji z wszystkimi interesariuszami, nie tylko poprzez sięganie do coraz to nowszych, bardziej różnorodnych form i narzędzi komunikacyjnych, ale przede wszystkim do sposobów zarządzania całościowym procesem komunikacji danego przedsiębiorstwa. Przed takim dylematem stanęły polskie uczelnie, w marcu 2020 roku, kiedy niebezpieczny wirus, SARS-Cov-2, dotarł do Polski.

Uczelnie wyższe, zarówno te publiczne jak i prywatne, to podmioty funkcjonujące na rynku usług edukacyjnych. Jest to rynek, na którym podobnie jak na innych rynkach, występuje również podaż i popyt.

Działania popytowe uczelni, należy rozumieć jako działania, których realizacja nie byłaby możliwa bez zaangażowania odpowiednio przygotowanej i wdrożonej w życie polityki informacyjnej (czyli działań z zakresu promocji, marketingu, ale również komunikacji społecznej). Do szczególnego rodzaju działań popytowych uczelni można zaliczyć [1]:

1. Kreacje popytu na usługi i działania edukacyjne.

2. Ciągły monitoring usług edukacyjnych i badawczych wraz $\mathrm{z}$ aktywnym marketingiem.

3. Kształtowanie wśród młodzieży szkół podstawowych, gimnazjów, szkół ponadgimnazjalnych za pośrednictwem mediów zainteresowania chęcią studiowania na proponowanych przez uczelnię kierunkach studiów.

Świadczone przez uczelnie wyższe, zarówno te państwowe jak i prywatne, usługi edukacyjne należy rozumieć, jako „kierowanie procesem zdobywania wiedzy oraz kształtowania osobowości" [2]. Przywołana definicja akcentuje na podstawowe cele szkół wyższych, ale również akcentuje na podejście rynkowe do procesu edukacji na poziomie samego szkolnictwa wyższego. Aby to podejście rynkowe mogło być realizowane przez wymienione powyżej podmioty ważne stają się relacje z potencjalnymi klientami (przyszłymi i obecnymi studentami), które powinny być odpowiednio komunikowane i tym samym stanowić również element komunikacji wewnętrznej i zewnętrznej. Usługa edukacyjna $z$ uwagi na swoją niematerialność, nierozdzielność, niejednorodność i nietrwałość, jako pewien specyficzny proces rozciągnięty w czasie wymaga odpowiedniego zaprojektowania i zarządzania nim [3]. Ponadto jako usługa profesjonalna, cechuje się także dużą indywidualizacją.

Koronawirus i wywołana przez wirusa SARS-CoV-2 pandemia spowodowały istotne zmiany w życiu całego globalnego świata. Praktycznie świat, jaki był nam do tej pory znany zmienił się $\mathrm{w}$ każdym aspekcie i kształcie. $\mathrm{Z}$ dnia na dzień w wyniku wielu obostrzeń wprowadzonych zarówno na świecie, jak i w Polsce zmienił się tradycyjny sposób funkcjonowania wielu podmiotów. Zdecydowanie umiejętność odnalezienia się $\mathrm{w}$ nowych warunkach, a w szczególności zastosowanie nowoczesnych technologii i rozwiązań bez wątpienia było dużym plusem dla przedsiębiorstw w różnych obszarach działalności. Obowiązujące restrykcje i ograniczenia wprowadzone $\mathrm{w}$ ramach walki $\mathrm{z}$ pandemią niestety uniemożliwiły wielu przedsiębiorstwom normalne funkcjonowanie. Brak możliwości kontaktów podmiotów z klientem a także brak sprzedaży bezpośredniej, przedsiębiorstwa zaczęły sobie rekompensować metodami wykorzystującymi nowoczesne technologie, 
komunikacją zdalną czy pracą na odległość. Dotarcie do potencjalnych klientów zastąpiono internetowymi kanałami, w tym mediami społecznościowymi. Dostosowując się do zaistniałej sytuacji wdrożono elektroniczny obieg dokumentów oraz systemy informatyczne do zarządzania przedsiębiorstwem [4]. Nowoczesne technologie, w tym ,nowe, nowe media” [5] okazały się bardzo użyteczne w funkcjonowaniu przedsiębiorstw w dobie lockdownu, w tym uczelni wyższych. Zdecydowanie uczelnie wyższe, które jeszcze przed pandemią wykorzystywały nowoczesne technologie mają i miały zdecydowanie lepszy punkt wyjścia w funkcjonowaniu w trwającej od prawie dwóch lat pandemii.

\section{Social media jako przykład nowoczesnych technologii i nowej formy komunikacji}

Cyfrowa i mobilna komunikacja z całą pewnością zawładnęła współczesnym światem (zwłaszcza w czasach pandemii), do tego stopnia, iż coraz więcej podmiotów czy organizacji oferuje swoim klientom kontakt za pośrednictwem mediów społecznościowych. Rewolucja komunikacyjna, której cały czas jesteśmy świadkiem sprawiła, że social media w ogóle się pojawiały, są i nadal aktywnie się rozwijają. Dane z raportu Hootsuite "Digital 2020" (styczeń 2020 rok) pokazują, że do najczęściej używanej platformy mediów społecznościowych należy Facebook $(2,449$ miliarda użytkowników). Za nim uplasował się najpopularniejszy serwis wideo, czyli YouTube (2 miliardami użytkowników). Trzecie miejsce przypadło komunikatorowi WhatsApp (1,6 miliarda użytkowników).

Media społecznościowe to nic innego jak nowe sposoby komunikacji, które powstaja i jednocześnie zmieniają się w zawrotnym tempie. Charakteryzując social media należy zwrócić uwagę na fakt, iż cechuje je niespotykana jak dotąd dostępność a także nieograniczona elastyczność [5,6]. Social media to nowe technologie, nowe środki przekazu - począwszy od Internetu (poczty elektronicznej, stron internetowych) aż po najnowsze nowinki technologiczne (iPhony, iPody czy smartfony), stanowiące sprzęt czy też nośniki w tym złożonym procesie komunikacji.

Charakteryzując nowe media za Janem van Dijk'iem [7] można wyróżnić i wskazać zarówno na ich właściwości strukturalne i techniczne, które ściśle wiążą się ze strukturalną jak i techniczną rewolucją komunikacyjną (integracja telekomunikacji, wymiany danych i komunikacji masowej w jednym medium oraz interaktywność). Techniczna rewolucja komunikacji wiążę się z techniczną cechą nowych mediów w postaci kodu binarnego, który „co prawda określa jedynie formę funkcjonowania nowych mediów, jednak ma również poważne konsekwencje dla samej komunikacji" [7]. To przekształcenie treści mediów na kod binarny ma swoje konsekwencje w postaci: ujednolicenia i standaryzacji treści; wzrostu liczby jednostek informacji i komunikacji, gdyż łatwiejsze jest ich wytwarzanie, nagrywanie i dystrybucja oraz rozerwania tradycyjnego linearnego uporządkowania dużych jednostek informacji i komunikatów na rzecz mediów hipertekstowych.

Social media to media, które cechuje: cyfrowość (kod binarny), wspomniana interaktywność (interaktywny odbiór) oraz hipertekstualność (niesekwencyjne połączenia pomiędzy wszelkimi rodzajami danych, dokonane dzięki technice komputerowej). Do powyższych cech można dodać również za Martinem Listerem, Jonem Dovey'em, Sethem Giddings'em, Iainem Grant'em i Kieranem Kelly 
wirtualność nowych mediów, usieciowienie (czyli ogólnoświatowa sieć Internetu) i symulacyjność [8].

Celem niniejszego artykułu jest analiza w jaki sposób i co państwowe uczelnie wyższe, w szczególności uczelnie techniczne, komunikowały otoczeniu wewnętrznemu i zewnętrznemu w globalnej sytuacji kryzysowej, jaką była i nadal jest pandemia koronowirusa za pomocą wybranych mediów społecznościowych. Na stronie Ministerstwa Edukacji i Nauki widnieje spis oraz podział polskich uczelni wyższych na: uczelnie publiczne, uczelnie niepubliczne, uczelnie kościelne oraz uczelnie $\mathrm{z}$ uprawnieniami do kształcenia poza granicami RP. W badaniach zostały uwzględnione tylko uczelnie publiczne akademickie nadzorowane przez Ministra. Poddane obserwacji uczelnie zostały odgórnie podzielone przez Ministerstwo na następujące kategorie: uniwersytety, uczelnie techniczne, uczelnie ekonomiczne, uczelnie pedagogiczne, uczelnie rolnicze/przyrodnicze, uczelnie wychowania fizycznego oraz uczelnie teologiczne.

Do analizy została wybrana reprezentatywna grupa 59 jednostek akademickich uczelni publicznych - prowadzących działalność naukowo-badawczą. Głównym celem przeprowadzonej analizy było wskazanie wykorzystania social media przez wybrane polskie instytucje akademickie do celów komunikacyjnych podczas pierwszej fali pandemii. Prowadzona analiza miała udzielić odpowiedzi na następujące pytania badawcze:

- Jakiego rodzaju informacje pojawiały się na oficjalnych profilach społecznościowych i stronach internetowych państwowych wyższych uczelni publicznych podczas I fali pandemii?

- W jakich dniach i ile się pojawiało postów/komunikatów na profilach społecznościowych szkół wyższych?

- Jak zamieszczane informacje angażowały odbiorców do aktywności wirtualnej - komentowania, lajkowania, udostępniania podczas I fali pandemii?

- Jaka była forma zamieszczanych postów podczas I fali pandemii?

Pozyskanie materiału do analizy polegało po pierwsze na odwiedzeniu głównej strony internetowej każdej uczelni akademickiej. Drugim etapem przeprowadzonego badania było poszukiwanie na głównej stronie uczelni linków do serwisów społecznościowych, poszukiwanie to polegało na wyszukiwaniu na stronie głównej uczelni ikon mediów społecznościowych. Trzeci etap to analiza tematyki wpisów zamieszczanych na stronach www uczelni i serwisach społecznościowych w okresie od 4 marca do 30 czerwca 2020.

\section{Uczelnie techniczne wyższe a social media}

Spośród 59 uczelni poddanych analizie praktycznie każda w badanym okresie posiadała własny profil społecznościowy na Facebooku (tabela 1), natomiast w przypadku innych mediów społecznościowych takich: Twitter, YouTube, Instagram, czy VK uczelnie miały co najmniej jeden z wskazanych profili. Dla porównania w 2012 roku co najmniej jeden profil w mediach społecznościowych posiadały tylko 42 jednostki akademickie [9]. W ciągu ostatnich lat obecność w social media okazała się znacząca dla wszystkich uczelni wyższych, i te które w 2012 lub 2017 roku nie angażowały się w komunikację za pośrednictwem narzędzi 
internetowych $\mathrm{w}$ dobie pandemii $\mathrm{w}$ znaczący sposób przeniosły swoją politykę informacyjną w stronę najważniejszego klienta, studentów, w nowoczesne narzędzia informacyjne, jakim są bez wątpienia social media.

Do najbardziej aktywnych, w sensie posiadania profili w mediach społecznościowych, należy zakwalifikować zarówno uczelnie techniczne (8 na 18 uczelni technicznych miało co najmniej 5 profili) jak i uczelnie ekonomiczne (wszystkie posiadały co najmniej 5 profili w mediach społecznościowych) [10]. Spośród publicznych uczelni wyższych to uczelnie techniczne w analizowanym okresie zauważyły możliwość a także konieczność wykorzystywania nowych mediów do szeroko pojętej komunikacji zarówno ze swoim otoczeniem zewnętrznym jak i wewnętrznym. To w przypadku tego rodzaju jednostek akademickich można odnotować wyraźny wzrost aktywności w media społecznościowych takich jak YouTube czy Instagram.

Tabela 1. Liczba uczelni posiadająca swój profil na Facebook'u w latach 2012, 2017, 2020 z uwzględnieniem rodzaju uczelni 9 (opracowanie własne)

\begin{tabular}{|l|c|c|c|c|}
\hline \multicolumn{1}{|c|}{ Rodzaj uczelni } & $\begin{array}{c}\text { Ogólna liczba } \\
\text { uczelni }\end{array}$ & $\begin{array}{c}\text { Liczba uczelni z } \\
\text { profilem na FB } \\
\text { w 2012 roku }\end{array}$ & $\begin{array}{c}\text { Liczba uczelni z } \\
\text { profilem na FB } \\
\text { w 2017 roku }\end{array}$ & $\begin{array}{c}\text { Liczba uczelni z } \\
\text { profilem na FB } \\
\text { w 2020 roku }\end{array}$ \\
\hline Uniwersytety & 18 & 14 & 18 & 18 \\
\hline Uczelnie techniczne & 18 & 13 & 17 & 18 \\
\hline Uczelnie ekonomiczne & 5 & 5 & 5 & 5 \\
\hline Uczelnie pedagogiczne & 5 & 4 & 5 & 5 \\
\hline $\begin{array}{l}\text { Uczelnie rolnicze/ } \\
\text { przyrodnicze }\end{array}$ & 6 & 4 & 6 & 6 \\
\hline $\begin{array}{l}\text { Uczelnie wychowania } \\
\text { fizycznego }\end{array}$ & 6 & 1 & 6 & 6 \\
\hline Uczelnie teologiczne & 1 & 0 & 1 & 1 \\
\hline Razem & 59 & 41 & 58 & 59 \\
\hline
\end{tabular}

W przypadku drugiego najpopularniejszego serwisu społecznościowego YouTube (tabela 2), w 2020 roku 53 uczelnie na 59 prowadziło swój oficjalny kanał w serwisie. Dla porównania w 2017 z YouTube'a korzystało 48 uczelni na 59, a w 2012 roku tylko 18 prowadziło swój oficjalny kanał w serwisie. Pierwszymi uczelniami, które w założyły oficjalne profile na YouTubie były: Politechnika Wrocławska i Uniwersytet Ekonomiczny w Poznaniu. W przypadku serwisu YouTube można zauważyć wyraźną tendencją wzrostową - wzrost użytkowników jeśli chodzi o publiczne uczelnie wyższe w przeciągu 5 lat wyniósł 166\%. Z zebranych danych w 2017 roku wynika, że największą liczbę osób obserwujących dany kanał uczelni posiadała Politechnika Wrocławska (10 467 osób), Uniwersytet Śląski w Katowicach (6 039 osób) oraz Uniwersytet Warszawski (3 327 osób). Średnia liczba subskrypcji (obserwacji danego kanału) dla wszystkich przebadanych uczelni wynosiła 742,5. Z kolei jeśli chodzi o średnią wartość subskrypcji w odniesieniu do rodzaju uczelni to największą liczbę obserwujących miały uniwersytety tj. 1 026,3 osób, uczelnie techniczne (1 007,8 osób) oraz uczelnie ekonomiczne (504,2 osób) [11]. 
Tabela 2. Liczba uczelni posiadajaca swój profil na YouTubie w latach 2017, 2020 z uwzględnieniem rodzaju uczelni (opracowanie własne)

\begin{tabular}{|l|c|c|c|}
\hline \multicolumn{1}{|c|}{ Rodzaj uczelni } & $\begin{array}{c}\text { Ogólna liczba } \\
\text { uczelni }\end{array}$ & $\begin{array}{c}\text { Liczba uczelni z } \\
\text { profilem na } \\
\text { YOUTUBIE } \\
\text { w 2017 roku }\end{array}$ & $\begin{array}{c}\text { Liczba uczelni z } \\
\text { profilem na } \\
\text { YOUTUBIE } \\
\text { w 2020 roku }\end{array}$ \\
\hline Uniwersytety & 18 & 16 & 18 \\
\hline Uczelnie techniczne & $\mathbf{1 8}$ & $\mathbf{1 5}$ & $\mathbf{1 6}$ \\
\hline Uczelnie ekonomiczne & 5 & 4 & 5 \\
\hline Uczelnie pedagogiczne & 5 & 4 & 6 \\
\hline $\begin{array}{l}\text { Uczelnie } \\
\text { rolnicze/przyrodnicze }\end{array}$ & 6 & 5 & 0 \\
\hline $\begin{array}{l}\text { Uczelnie wychowania } \\
\text { fizycznego }\end{array}$ & 6 & 4 & 53 \\
\hline Uczelnie teologiczne & 1 & 0 & 4 \\
\hline Razem & 59 & 48 & \\
\hline
\end{tabular}

Na miejscu trzecim, wśród najpopularniejszych social media uczelni publicznych, znalazł się Instagram, który stanowi ciekawe medium (tabela 3). Obecnie korzysta z niego 81\% przebadanych publicznych uczelni wyższych. Zarówno w 2017 jak i 2020 roku to uczelnie techniczne najczęściej maiły swoje profile na Instagramie. W 2017 roku najwięcej obserwujących w serwisie Instagram posiadał profil Politechniki Wrocławskiej, tj. 9411 obserwujących. Jeśli chodzi o średnią liczbę osób obserwujących dany profil uczelni w 2017 roku na Instagramie to wynosiła ona 2686,7 osób [10].

Tabela 3. Liczba uczelni posiadająca swój profil na Instagramie w latach 2017, 2020 z uwzględnieniem rodzaju uczelni (opracowanie własne)

\begin{tabular}{|l|c|c|c|}
\hline \multicolumn{1}{|c|}{ Rodzaj uczelni } & $\begin{array}{c}\text { Ogólna liczba } \\
\text { uczelni }\end{array}$ & $\begin{array}{c}\text { Liczba uczelni z } \\
\text { profilem na } \\
\text { INSTAGRAMIE } \\
\text { w 2017 roku }\end{array}$ & $\begin{array}{c}\text { Liczba uczelni z } \\
\text { profilem na } \\
\text { INSTAGRAMIE } \\
\text { w 2020 roku }\end{array}$ \\
\hline Uniwersytety & 18 & 10 & 14 \\
\hline Uczelnie techniczne & $\mathbf{1 8}$ & $\mathbf{1 1}$ & $\mathbf{1 5}$ \\
\hline Uczelnie ekonomiczne & 5 & 4 & 5 \\
\hline $\begin{array}{l}\text { Uczelnie } \\
\text { pedagogiczne }\end{array}$ & 5 & 4 & 3 \\
\hline $\begin{array}{l}\text { Uczelnie rolnicze/ } \\
\text { przyrodnicze }\end{array}$ & 6 & 5 & 0 \\
\hline $\begin{array}{l}\text { Uczelnie wychowania } \\
\text { fizycznego }\end{array}$ & 6 & 0 & 48 \\
\hline Uczelnie teologiczne & 1 & 0 & \\
\hline Razem & 59 & 34 & \\
\hline
\end{tabular}




\section{Uczelnie wyższe na Facebook'u podczas I fali pandemii}

Facebook to zdecydowanie najbardziej popularny serwis społecznościowy w jaki są zaangażowane publiczne uczelnie wyższe w Polsce. Do grona najbardziej aktywnych uczelni w serwisie społecznościowym Facebook (tabela 4) w objętym analizą okresie (od 4 marca do 30 czerwca 2020) zdecydowanie należy Uniwersytet Warmińsko-Mazurski w Olsztynie - 382 postów. Na drugim miejscu znalazła się Politechnika Koszalińska - 229 postów a na trzecim Politechnika Poznańska - 196 postów. Zdecydowanie podczas pierwszej fali pandemii to uczelnie techniczne publikowały największą liczbę postów na dzień.

Tabela 4. Największa liczba postów przypadająca na uczelnie w badanym okresie (opracowanie wtasne)

\begin{tabular}{|c|c|}
\hline Uczelnia & $\begin{array}{c}\text { Liczba postów w badanym } \\
\text { okresie }\end{array}$ \\
\hline Uniwersytet Warmińsko-Mazurski w Olsztynie & 382 postów \\
\hline Politechnika Koszalińska & 229 postów \\
\hline Politechnika Poznańska & 196 postów \\
\hline Politechnika Wrocławska & 188 postów \\
\hline Uniwersytet Wrocławski & 187 postów \\
\hline Uniwersytet Przyrodniczy w Poznaniu & 176 postów \\
\hline Politechnika Łódzka & 165 postów \\
\hline Uniwersytet Ekonomiczny w Krakowie & 158 postów \\
\hline Uniwersytet Zielonogórski & 156 postów \\
\hline $\begin{array}{l}\text { Uniwersytet Marii } \quad \text { Curie-Skłodowskiej } \\
\text { w Lublinie }\end{array}$ & \\
\hline $\begin{array}{l}\text { Akademia Wychowania } \\
\text { we Wrocławiu }\end{array}$ & \\
\hline
\end{tabular}

Jeśli chodzi o treść postów to były to przede wszystkim posty nie dotyczące problematyki koronowirusa - 70,70\%, te dotyczące funkcjonowania uczelni podczas pandemii stanowiły 22,60\% a dotyczące bezpośrednio COVID-19 6,70\%. Do grona uczelni, które zamieściły $\mathrm{w}$ analizowanym okresie najwięcej postów związanych z funkcjonowaniem uczelni podczas COVID-19 należy zdecydowanie uczelnia techniczna Politechnika Koszalińska (80 postów) oraz na drugim miejscu Politechnika Poznańska (71 postów). Na dalszych pozycjach znalazły się: Uniwersytet Warmińsko-Mazurski w Olsztynie (55 postów), Zachodnipomorski Uniwersytet Technologiczny w Szczecinie (46 posty) oraz Uniwersytet Warszawski (44 posty).

Treść postów z kategorii funkcjonowanie uczelni podczas pandemii dotyczyła przede wszystkim:

- informacji na temat nauczania zdalnego (247 postów) - 17,0\%;

- zarządzeń Rektora i Prorektora dotyczących funkcjonowania Uczelni w czasie pandemii (213 postów) - 15,0\%;

- informacji na temat kontaktu z uczelnią podczas pandemii (100 postów) - 7,0\%;

- informacji dotyczących funkcjonowania biblioteki uczelnianej (80 postów) - 6,0\%;

- kategoria inne (448 postów) - 32,0\%. 
Zdecydowanie adresatem/odbiorcą zamieszanych komunikatów była cała społeczność akademicka - 67,6\% postów miało takiego odbiorcę. W następnej kolejności adresatami byli tylko studenci - 29,0\%, do kandydatów na studia skierowanych było 1,4\% postów a do pracowników uczelni - 0,7\% postów. Kategoria inne, w której znajdowały się różne podmioty $\mathrm{z}$ otoczenia zewnętrznego uczelni stanowiła 1,3\% wszystkich postów tej kategorii.

Z kolei jeśli chodzi o uczelnie, które w badanym okresie zamieściły najwięcej postów związanych z samym wirusem COVID-19 należy w pierwszej kolejności wskazać: Uniwersytet Ekonomiczny w Krakowie (33 posty) oraz Uniwersytet Śląski w Katowicach (25 postów). Na dalszym miejscu pojawiają się uczelnie techniczne: Politechnika Wrocławska (22 posty) i Politechnika Poznańska (22 posty). Miejsce piąte to Uniwersytet Warmińsko-Mazurski w Olsztynie (21postów).

Treść postów z kategorii INFORMACJE O COVID-19 dotyczyła przede wszystkim: - informacji o wirusie SARS COV-2 (127 postów) - 30,0\%;

- informacji dotyczących ogólnych obostrzeń i zakazów (58 postów) - 14,0\%;

- informacji jak rozpoznać objawy COVID-19 (56 postów) - 13,0\%;

- informacji o webinarach o COVID-19 (54 posty) - 12,0\%;

- kategoria inne (35 postów) - 8,0\%.

W tym przypadku tak samo głównym adresatem/odbiorcą zamieszanych komunikatów była cała społeczność akademicka - 82\% postów miało takiego odbiorcę. W następnej kolejności adresatami byli inni - 13,0\% oraz tylko studenci $5,0 \%$ postów.

Użytkownicy publikujący posty w mediach społecznościowych, w tym przypadku państwowe uczelnie wyższe, oczekują, że zamieszczone posty wywołają pewien rezonans wśród innych użytkowników danego portalu. W przypadku serwisu Facebook rezonans ten można diagnozować za pomocą kilku wskaźników — liczby komentarzy, liczby tzw. lajków (,lubię to”), liczby wskazań „,super”, „wow”, „wrr”, „haha” i „przykro”, a także liczby kolejnych udostępnień. W ten sposób można określić, jak duży jest zasięg danego wpisu oraz jaką wzbudza reakcję pozostałych użytkowników profilu. W przypadku postów jakie pojawiały się na profilach facebookowych państwowych uczelni wyższych wyraźnie można wskazać, że najczęściej komentowane były informacje dotyczące funkcjonowania uczelni podczas pandemii (6,6 komentarzy na jeden post). Jeśli chodzi o wskaźniki dotyczące gamy emocji, to zdecydowanie najczęściej „lajkowano” posty dotyczące informacji o COVID-19 (średnio 83,3 lajków na post), na drugim miejscu posty nie związane W żaden sposób $\mathrm{z}$ wirusem i funkcjonowaniem uczelni podczas pandemii (61,8 lajków) i posty dotyczące funkcjonowanie uczelni podczas pandemii (średnio 57,8 polubień). Natomiast najczęściej udostępniano posty dotyczące COVID-19 (tabela 5) - średnio 79,6 razy, co za pewne wynika z faktu, że dla wszystkich śmiertelny wirus był całkowicie czymś nowym i nieznanym. 
Tabela 5. Średnie zaangażowanie fanów fanpaga uczelni $w$ stosunku do publikowanych postów (opracowanie własne)

\begin{tabular}{|l|c|c|c|}
\hline Rodzaj rezonansu & posty o COVID-19 & $\begin{array}{c}\text { posty dotyczące } \\
\text { funkjonowania uczelni } \\
\text { podczas pandemii }\end{array}$ & inne posty \\
\hline komentarze & 5,9 & 6,6 & 4,8 \\
\hline like & 83,3 & 57,8 & 61,8 \\
\hline super & 14,6 & 13,3 & 16 \\
\hline trzymaj się & 0,1 & 0,2 & 0,3 \\
\hline haha & 0,7 & 1 & 2,3 \\
\hline wow & 1,1 & 1,7 & 0,6 \\
\hline płacz & 1,3 & 3,1 & 0,7 \\
\hline udostępnianie & 79,6 & 13,3 & 6,4 \\
\hline
\end{tabular}

\section{Wnioski końcowe}

Serwisy społecznościowe to bez wątpienia, najpopularniejsze narzędzia komunikacyjne globalnego świata, co z całą pewnością potwierdzają poddane analizie działania dotyczące polityki informacyjnej państwowych uczelni wyższych. W odniesieniu do prezentowanej analizy zdecydowanie to uczelnie techniczne najczęściej wykorzystywały tego rodzaju narzędzia do komunikacji ze społecznością akademicką. W obliczu rozpoczynającej się pandemii informacje o samym wirusie i funkcjonowaniu uczelni w tych trudnych czasach nie były tematem przewodnim publikowanych postów, bowiem aż $70,7 \%$ postów dotyczyło innej tematyki, co świadczy o tym, że w obliczu zmian i trwającej rewolucji komunikacyjnej polskie uczelnie zauważyły nie tylko możliwość, ale konieczność wykorzystywania social mediów w procesie szeroko rozumianego procesu komunikowania. Przede wszystkim komunikowania interaktywnego, bazującego na dwustronnej interaktywnej komunikacji z otoczeniem, zarówno tym wewnętrznym jak i zewnętrznym, za pomocą różnych narzędzi i kanałów internetowych.

\section{LITERATURA}

1. WAWAK T.: Jakość zarządzania w szkołach wyższych. Wydawnictwo Uniwersytetu Jagiellońskiego, Kraków 2012.

2. KULIG A.: Rynek usługi edukacyjnej w Polsce na poziomie wyższym. W: Nowaczyk G., Kolasiński M. (red.): Marketing szkół wyższych. Wydawnictwo Wyższej Szkoły Bankowej w Poznaniu, Poznań 2004.

3. DRAPIŃSKA A.: Zarządzanie relacjami na rynku usług edukacyjnych szkół wyższych. Wydawnictwo Naukowe PWN, Warszawa 2011.

4. DĘBKOWSKA K., KŁOSIEWICZ-GÓRECKA U., LEŚNIEWICZ F., SZYMAŃSKA A., ŚWIĘCICKI I., WAŻNIEWSKI P., ZYBERTOWICZ K.: Nowoczesne technologie w przedsiębiorstwach przed, w trakcie i po pandemii COVID-19. Polski Instytut Ekonomiczny, Warszawa 2020.

5. LEVINSON P.: Nowe nowe media. Wydawnictwo WAM, Kraków 2010. 
6. BĄK A.: Globalny świat i globalna komunikacja: nowe media i ich współczesne funkcje. Akademia Techniczno-Humanistyczna, Bielsko-Biała 2015.

7. van DIJK J.A.: Społeczne aspekty nowych mediów. Wydawnictwo PWN, Warszawa 2010.

8. LISTER M., DOVEY J., GIDDINGS S., GRANT I., KELLY K.: Nowe media. Wprowadzenie. Przek. LOREK M., SADZA A., SAWICKA K., Wydawnictwo Uniwersytetu Jagiellońskiego, Kraków 2009.

9. KULCZYCKI E.: Wykorzystanie mediów społecznościowych przez akademickie uczelnie wyższe w Polsce. Badanie w formule otwartego notatnika, 2012.

10. BĄK A.: Świat social media a polskie uczelnie: o wykorzystywaniu mediów społecznościowych przez akademickie uczelnie wyższe. W: Oblicza komunikacji: polityka, instytucje publiczne, biznes. Red. BĄK-SZOŁUCHA A., KUBIUSZMUŁA Ł., Wydawnictwo Naukowe Akademii Techniczno-Humanistycznej, Bielsko-Biała 2018.

11. BĄK A.: W świecie Youtube'a - akademickie uczelnie wyższe w Polsce i ich oficjalne profile na kanale YouTube. W: Oblicza komunikacji: polityka, instytucje publiczne, biznes. Red. BĄK-SZOŁUCHA A., KUBIUSZ-MUŁA Ł., Wydawnictwo Naukowe Akademii Techniczno-Humanistycznej, Bielsko-Biała 2018. 